\title{
Supporting information materials for \\ Improved efficiency of PbS quantum dot sensitized NiO \\ photocathodes with naphthalene diimide electron acceptor bound to the surface of the nanocrystals
}

Mahfoudh Raissi, ${ }^{\mathrm{a} \dagger}$ Muhammad T. Sajjad, ${ }^{\mathrm{b} \dagger}$ Yoann Farré, ${ }^{\mathrm{a}}$ Thomas Roland, ${ }^{\mathrm{b}}$ Arvydas Ruseckas, ${ }^{\text {b }}$ Ifor D. W. Samuel, ${ }^{* b}$ Fabrice Odobel*a

${ }^{a}$ CEISAM, Chimie Et Interdisciplinarité, Synthèse, Analyse, Modélisation, CNRS, UMR CNRS 6230, UFR des Sciences et des Techniques ; 2, rue de la Houssinière - BP 92208; 44322 NANTES Cedex 3 (France)

E-mail: Fabrice.Odobel@univ-nantes.fr

${ }^{b}$ Organic Semiconductor Centre, SUPA, School of Physics and Astronomy, University of St Andrews, North Haugh, St Andrews, Fife, (United Kingdom).

E-mail:idws@st-andrews.ac.uk

\section{Synthesis of the ligand py-NDI}

\section{Generalities}

${ }^{1} \mathrm{H},{ }^{13} \mathrm{C}$ and ${ }^{31} \mathrm{P}$ NMR spectra were recorded on an AVANCE 300 UltraShield BRUKER and AVANCE 400 BRUKER. Chemical shifts for ${ }^{1} \mathrm{H}$ and ${ }^{13} \mathrm{C}$ NMR spectra are referenced relative to residual protium in the deuterated solvent $\left(\mathrm{CDCl}_{3} \delta=7.26 \mathrm{ppm}\right.$ for ${ }^{1} \mathrm{H}$ and $\delta=77.16 \mathrm{ppm}$ for $\left.{ }^{13} \mathrm{C}\right)$ or to an internal reference (TMS, $\delta=0 \mathrm{ppm}$ for both ${ }^{1} \mathrm{H}$ and ${ }^{13} \mathrm{C}$ ). NMR spectra were recorded at room temperature, chemical shifts are written in ppm and coupling constants in Hz. High-resolution mass (HR-MS) spectra were obtained either by electrospray ionization coupled with high resolution ion trap orbitrap (LTQOrbitrap, ThermoFisher Scientific,) or by MALDI-TOF-TOF (Autoflex III, Bruker), working in ionpositive or ion-negative mode. Electrochemical measurements were made under an argon atmosphere in the mixture $\mathrm{CH}_{2} \mathrm{Cl}_{2} / \mathrm{DMF}$ : $95 / 5$ with $0.1 \mathrm{M} \mathrm{Bu}_{4} \mathrm{NPF}_{6}$. Cyclic voltammetry experiments were performed by using a SP300 Bio-Logic potentiostat/galvanostat. A standard three-electrode electrochemical cell was used. Potentials were referred to a saturated calomel electrode as internal reference. All potentials are quoted relative to SCE. The working electrode was a glassy carbon disk and the auxiliary electrode was a Pt wire. In all the experiments the scan rate was $100 \mathrm{mV} \cdot \mathrm{s}^{-1}$. 
Chemicals were purchased from Sigma-Aldrich or Alfa Aesar and used as received. Thin-layer chromatography (TLC) was performed on aluminium sheets precoated with Merck 5735 Kieselgel $60 \mathrm{~F}_{254}$. Column chromatography was carried out either with Merck 5735 Kieselgel 60F (0.040-0.063 mm mesh). NDI derivative 2 as prepared according to literature.[1]

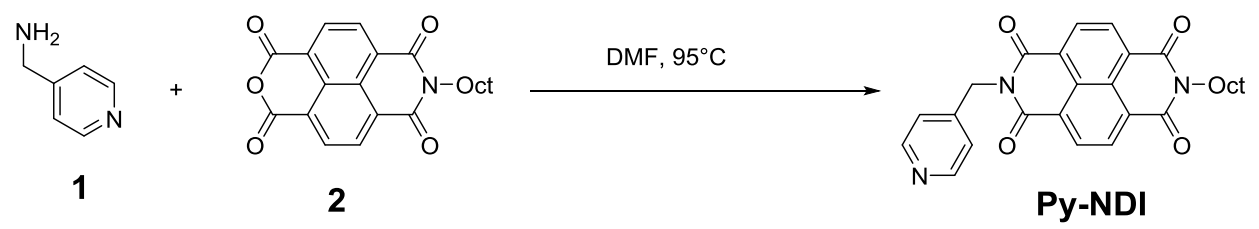

Compound 2 (582 mg, $1.53 \mathrm{mmol}, 1.0 \mathrm{eq}$ ) was dissolved in $25 \mathrm{~mL}$ of dry DMF under argon. The solution was heated at $120^{\circ} \mathrm{C}$ during $15 \mathrm{~min}$. (4-aminomethyl)-pyridine 1 (332 mg, $\left.3.07 \mathrm{mmol}, 2.0 \mathrm{eq}\right)$ in dry DMF (5 mL) was added dropwise in the reaction mixture (over $10 \mathrm{~min}$ ). The solution was stirred at $95^{\circ} \mathrm{C}$ overnight. The solvent was removed by evaporation and the residue taken up in dichloromethane. The organic layer was washed with distilled water (5x), dried over anhydrous $\mathrm{MgSO}_{4}$, filtered and concentrated under reduced pressure. The resulting product was purified by column chromatography (eluent: dichloromethane/methanol, 99/1, v/v). The desired product Py-NDI was obtained in 46\% yield (330 mg). ${ }^{1} \mathrm{H}$ NMR $\left(300 \mathrm{MHz}, \mathrm{CDCl}_{3}, 25^{\circ} \mathrm{C}\right), \delta(\mathrm{ppm}): 8.77$ (s, 4H), 8.55 (br d, J=4.8 Hz, 2H), 7.38 (d, $\mathrm{J}=5.7 \mathrm{~Hz}, 2 \mathrm{H}), 5.38(\mathrm{~s}, 2 \mathrm{H}), 4.18(\mathrm{~m}, 4 \mathrm{H}), 3.91$ (t, J=6.3 Hz, 4H), $1.73(\mathrm{~m}, 2 \mathrm{H}), 1.26-1.41(\mathrm{~m}, 10 \mathrm{H})$, $0.86(\mathrm{t}, \mathrm{J}=6.6 \mathrm{~Hz}, 3 \mathrm{H}) .{ }^{13} \mathrm{C} \mathrm{NMR}\left(75 \mathrm{MHz}, \mathrm{CDCl}_{3}, 25^{\circ} \mathrm{C}\right), \delta(\mathrm{ppm}): 162.8,162.7,150.2,145.1,131.4$, 131.0, 127.1, 128.8, 126.1, 123.4, 43.0, 41.1, 31.8, 29.3, 29.2, 28.1, 27.1, 22.6, 14.1. HRMS (MALDI, Dithranol/ $\mathrm{CH}_{3} \mathrm{CN}$ ) m/z: $[\mathrm{M}+\mathrm{H}]^{+}$calculated for $\mathrm{C}_{28} \mathrm{H}_{28} \mathrm{~N}_{3} \mathrm{O}_{4}, 470.2074$; found, 470.2083. $\Delta=1.9 \mathrm{ppm}$.

\section{Fabrication of solar cell}

Conductive glass substrates (F-doped $\mathrm{SnO}_{2}$, purchased from Pilkington (TEC15, sheet resistance 15 $\Omega /$ square) were successively cleaned by sonication in soapy water, then ethanol for $10 \mathrm{~min}$ before being fired at $450{ }^{\circ} \mathrm{C}$ for $30 \mathrm{~min}$. Once cooled down to room temperature, FTO plates were rinsed with ethanol and dried in ambient air. The $\mathrm{PbS}$ quantum dots were prepared according to the procedure previously reported.[2,3]

$\mathrm{NiO}$ dense layer were prepared by spin-coating a nickel acetate $(0.5 \mathrm{M})$ with $(0.5 \mathrm{M})$ ethanolamine in methoxyethanol solution at $2000 \mathrm{rpm}, 30 \mathrm{~s}$ followed by thermal treatment at $500^{\circ} \mathrm{C}, 0.5 \mathrm{~h}$. Thickness of $\mathrm{NiO}$ dense layer $(30 \pm 5 \mathrm{~nm})$. Then, $\mathrm{NiO}$ mesoporous layer deposited on this layer by screen-printing by using a commercial semiautomatic screen printer. The NiO screen-printing paste was produced by preparing a slurry of $3 \mathrm{~g}$ of $\mathrm{NiO}$ nanopowder (Inframat) suspended in $10 \mathrm{~mL}$ of distilled ethanol and ball-milled $(500 \mathrm{rpm})$ for $24 \mathrm{~h}$. The resulting slurry was mixed in a round-bottom flask with $10 \mathrm{ml}$ of 10 
wt\% ethanolic ethyl cellulose (Sigma Aldrich) solution and $20 \mathrm{ml}$ terpineol, followed by slow ethanol removal by rotary evaporation. The dried film was calcined in air at $400{ }^{\circ} \mathrm{C}$ for $0.5 \mathrm{~h}$. The prepared $\mathrm{NiO}$ electrodes were soaked in $20 \mathrm{mM} \mathrm{Ni}\left(\mathrm{CH}_{3} \mathrm{COOH}\right)_{2}$ with $1 \%$ tetraethanolamine in ethanol solution for 30 min at $60^{\circ} \mathrm{C}$ followed by ethanol rinsing at $60^{\circ} \mathrm{C}$ during $30 \mathrm{~min}$ and drying at $120^{\circ} \mathrm{C}, 2 \mathrm{~h}$. The thickness of $\mathrm{NiO}$ films $(\sim 3.5 \mu \mathrm{m})$.

$\mathrm{NiO}$ electrodes were treated with 35\% MPA in acetonitrile for $3 \mathrm{~min}$ and dried in air. The film was immersed in $\mathrm{PbS}$ CQDs solution $(50 \mathrm{mg} / \mathrm{ml})$ for overnight. The NiO-PbS films were passivated with CTAB (cetyltrimethylammonium bormide) in methanol $(10 \mathrm{mg} / \mathrm{ml}$ ) for $5 \mathrm{~min}$ and rinsed with methanol to remove $\mathrm{CTAB}$ excess. This process was repeated three time to increase the QDs loading and remove more the isolate ligands of oleic acid. Then, the PbS-TBAI/NiO sample was socked with Py-NDI solution $(1 \mathrm{mg} / \mathrm{ml}$ in toluene) during $2 \mathrm{~h}$ and rinsing with toluene.

Electrolyte used are composed of $0.1 \mathrm{M} \mathrm{Co}^{\mathrm{II}}(\mathrm{dtb}-\mathrm{bpy})_{3}, 0.1 \mathrm{M} \mathrm{Co}^{\mathrm{III}}(\mathrm{dtb}-\mathrm{bpy})_{3}$ and $0.1 \mathrm{M} \mathrm{LiClO}_{4}$ in propylene carbonate for cobalt complex as redox shuttle. Counter electrode were prepared by chemical deposition of platinum from hexachloroplatinic acid in distilled isopropanol (10 $\mathrm{mg}$ per $\mathrm{mL})$. The two electrodes were placed on top of each other using a thin transparent film of Surlyn polymer (DuPont, 25 $\mu \mathrm{m})$ as a spacer to form the electrolyte space. The empty cell was tightly held, and the edges were heated to $110{ }^{\circ} \mathrm{C}$ to seal the two electrodes together. A drop of electrolyte was introduced through a predrilled hole in the counter electrode by vacuum backfilling, and was sealed afterward. The cell had an active area of $c a .0 .25 \mathrm{~cm}^{2}$.

The current-voltage characteristics were determined by applying an external potential bias to the cell and measuring the photocurrent using a Keithley model 2400 digital source meter. The solar simulator is an Oriel Lamp calibrated to $100 \mathrm{~mW} / \mathrm{cm}^{2}$. The overall conversion efficiency $(\eta)$ of the photovoltaic cell is calculated from the integral photocurrent density $\left(\mathrm{J}_{\mathrm{sc}}\right)$, the open-circuit photovoltage $\left(\mathrm{V}_{\mathrm{oc}}\right)$, the fill factor of the cell (FF), and the intensity of the incident light ( $\left.\mathrm{I}_{\mathrm{Ph}}\right)$. 


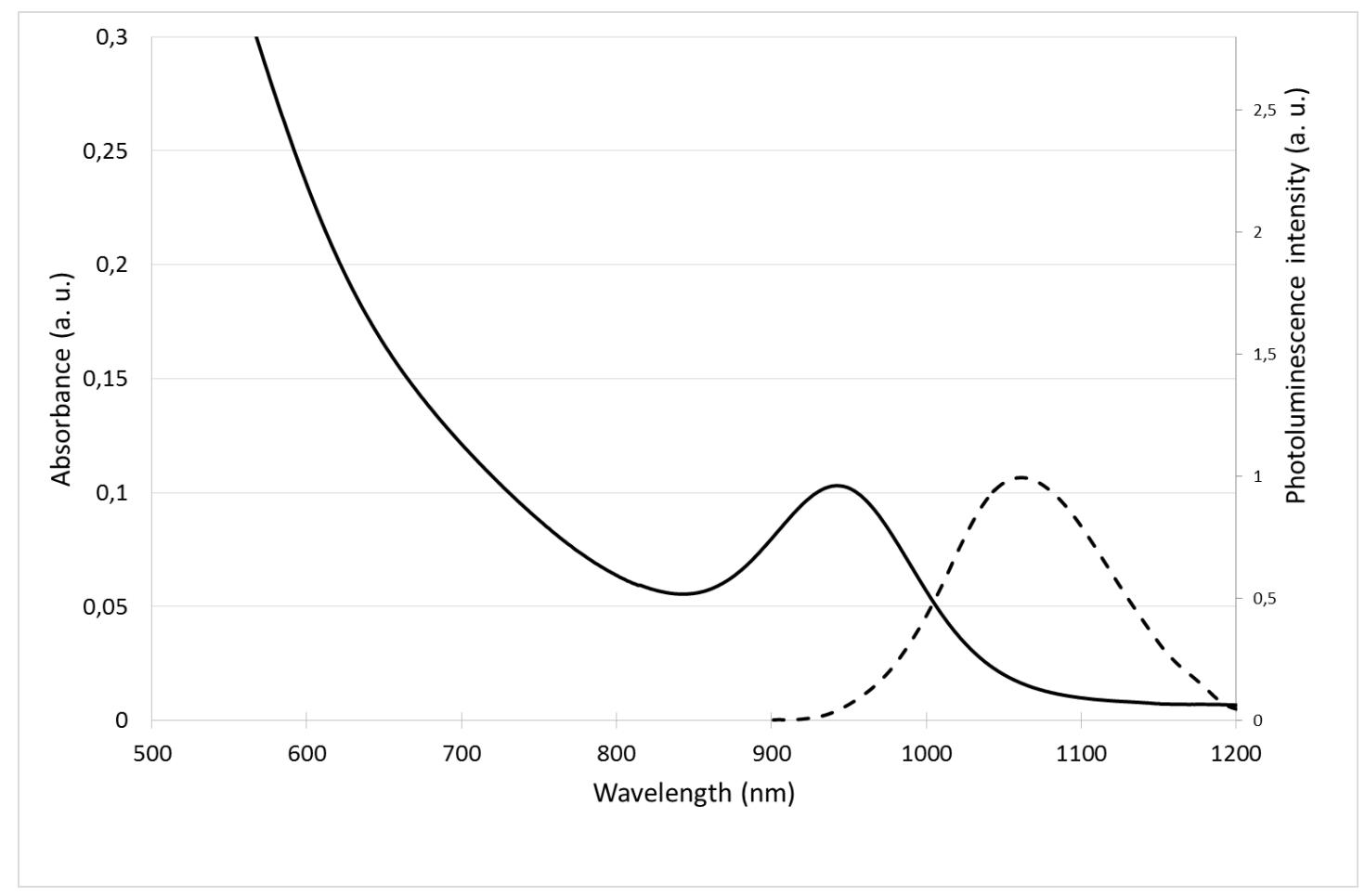

Figure S1. Absorption (straight line) and photoluminescence (dashed line) spectra of the PbS-TBAI QDs recorded in toluene solution. The sample was excited at $700 \mathrm{~nm}$.

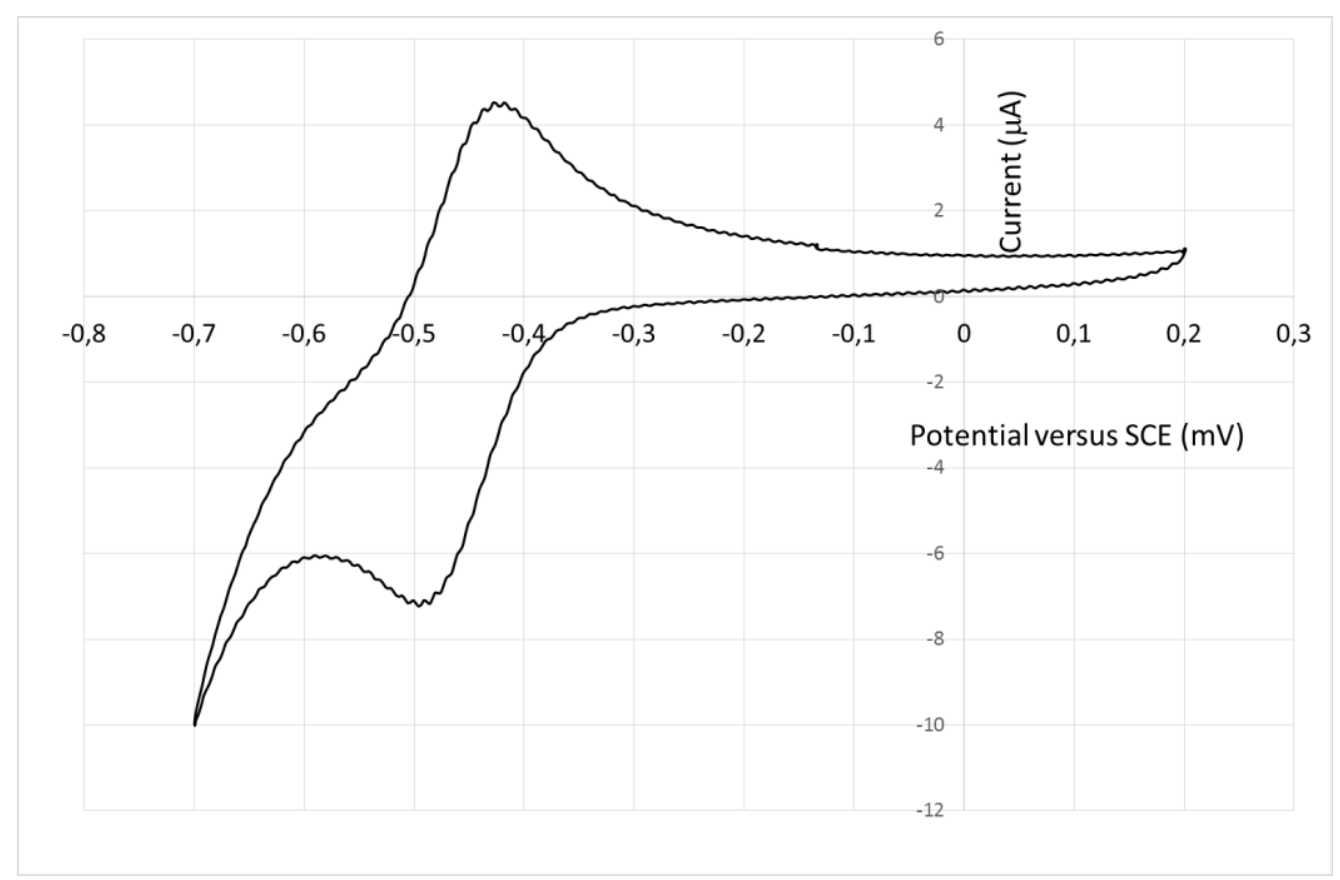

Figure S2. Cyclic voltammogram of py-NDI recorded in $\mathrm{CH}_{3} \mathrm{CN}$ with $\mathrm{Bu}_{4} \mathrm{NClO}_{4}$ as supporting electrolyte $(0.1 \mathrm{M})$, rate $100 \mathrm{mV} / \mathrm{sec}$. 


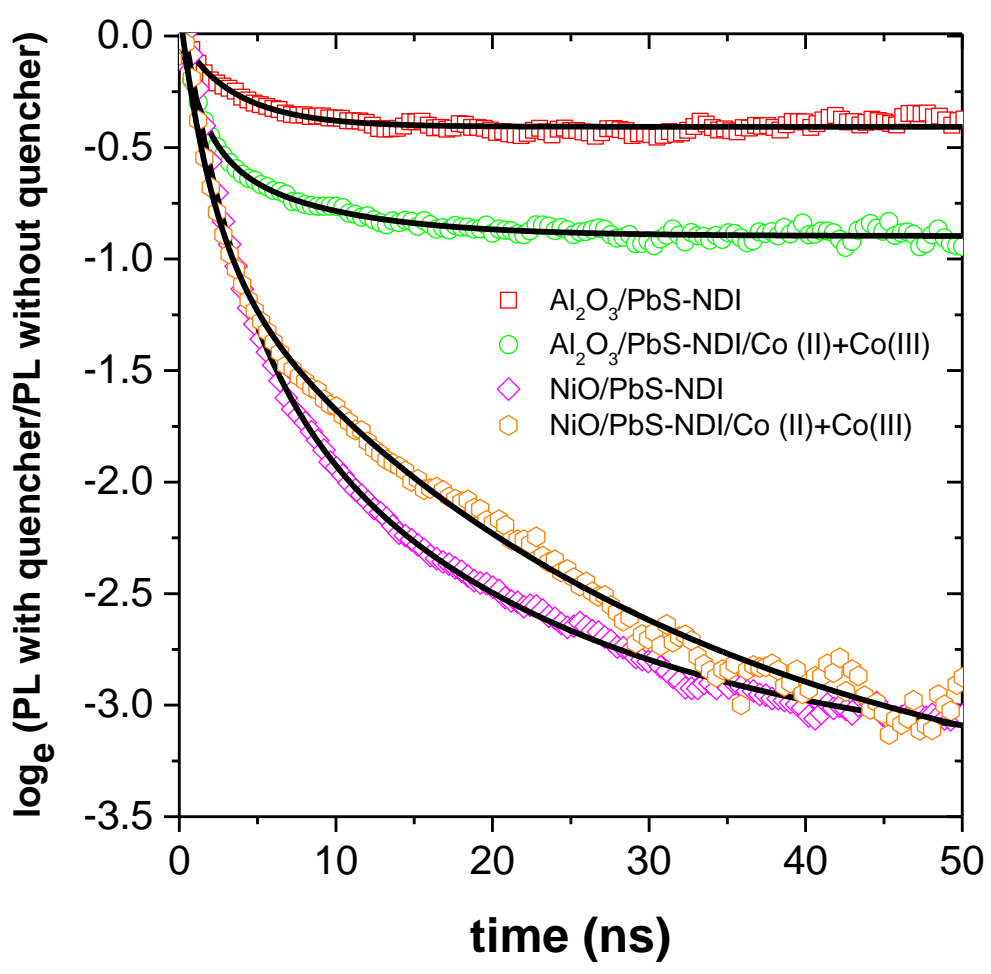

Figure S3. Ratio of photoluminescence kinetics of the $3.0 \mathrm{~nm} \mathrm{PbS}$ QDs with quencher (electron/hole acceptor) to photoluminescence kinetics without quencher (i.e on alumina). The solid black lines are fits to PL decays

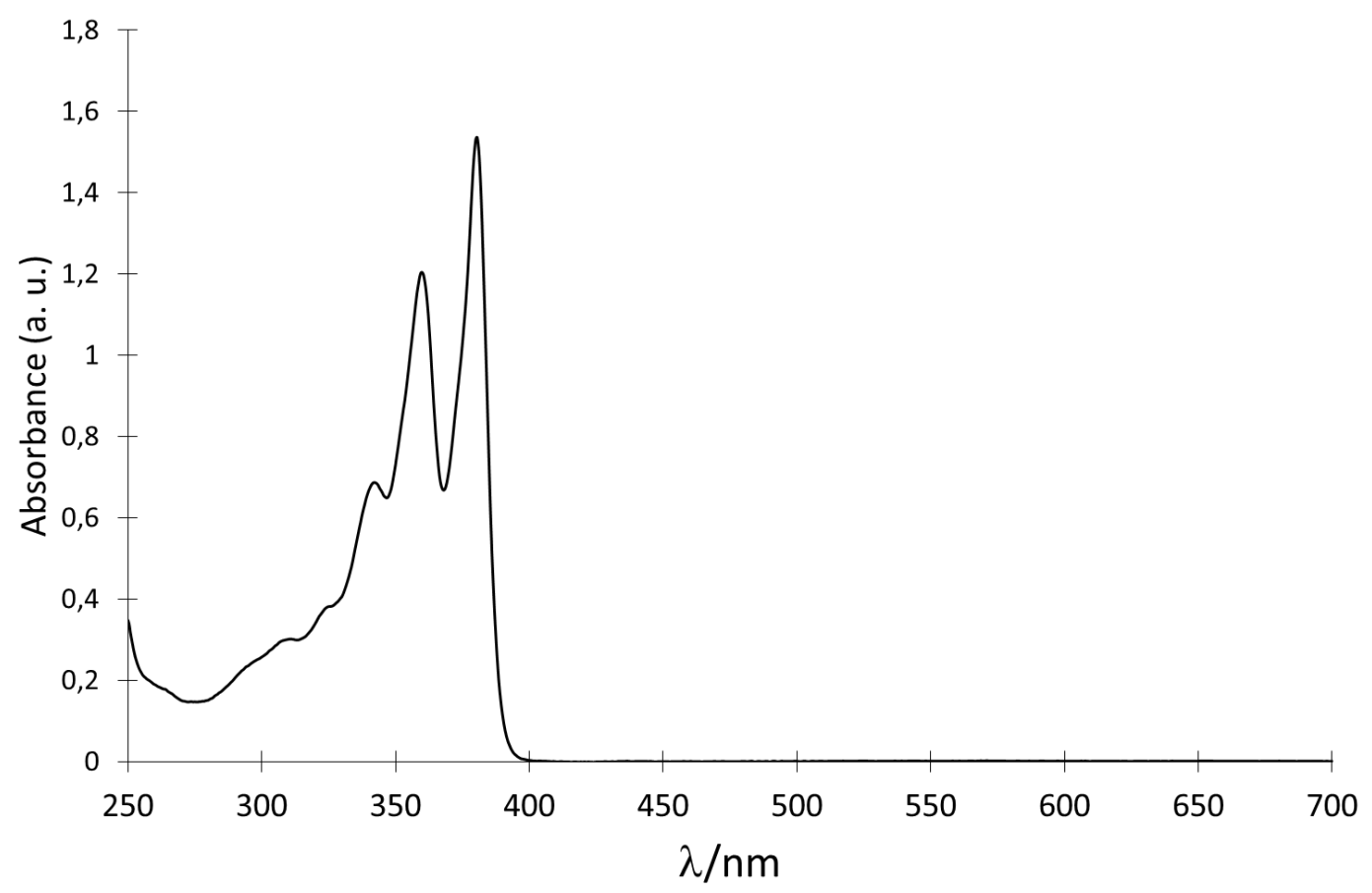

Figure S4. Absorption spectrum of py-NDI recorded in dichloromethane solution. 


\section{References:}

[1] M. J. Fuller, M. R. Wasielewski, Photorefractivity in Nematic Liquid Crystals Using a Donor-Acceptor Dyad with a Low-Lying Excited Singlet State for Charge Generation. J. Phys. Chem. B 105 (2001) 7216-7219.

[2] Mahfoudh Raissi, M. T. Sajjad, Y. Pellegrin, T. Roland, S. Jobic, M. Boujtita, A. Ruseckas, I. D. W. Samuel, F. Odobel, Size dependence of efficiency of PbS quantum dots in NiO-based dye sensitised solar cells and mechanistic charge transfer investigation. Nanoscale (2017).

[3] M. Raissi, Y. Pellegrin, S. Jobic, M. Boujtita, F. Odobel, Infra-red photoresponse of mesoscopic NiO-based solar cells sensitized with PbS quantum dot. Sci. Rep. 6 (2016) doi: 10.1038/srep24908. 